\title{
Controlled therapeutic trial of levamisole and sulphasalazine in acute ulcerative colitis
}

\author{
A HERMANOWICZ, A NOWAK, AND L GAJOS \\ From the Departments of Gastroenterology and Radiology, Silesian School of Medicine, Katowice, Poland
}

SUMmARY Forty five patients with acute ulcerative colitis were randomly allocated to receive (a) sulphasalazine, (b) levamisole, or (c) a combination of sulphasalazine and levamisole. Each group contained 15 patients. The ulcerative colitis activity index (UCAI), the remission and relapse rates were compared at three monthly intervals for one year. The UCAI fell in each group. Detailed analysis of all clinical and biochemical parameters used for estimation of UCAI showed that the only difference was in patients receiving combined therapy who continued to have a raised ESR and platelet count. Fewer patients, however, went into remission on levamisole therapy $(46.6 \%)$ compared with the other two groups $(66 \cdot 6 \%)$. The cumulative relapse rate was $20 \%$ for those receiving levamisole compared with $6.6 \%$ in the other groups. Side effects were observed in $20 \%$ of patients receiving levamisole, $26 \%$ receiving sulphasalazine, and $40 \%$ in those having combined therapy. The results indicate that levamisole is unlikely to have a major role in the management of patients with ulcerative colitis.

Ulcerative colitis is an inflammatory disease of the colonic mucosa. Its aetiopathogenesis is poorly understood although abberations in the immune system may be involved, both humoral ${ }^{12}$ and cellular $^{3-7}$ responses being implicated.

As levamisole is able to modulate the humoral and cellular immune responses ${ }^{89}$ thereby acting as an immunostimulant, it was proposed to assess its therapeutic benefit in patients with ulcerative colitis. Immunosuppressive agents, apart from corticosteroids, ${ }^{10}$ have proved disappointing in the management of acute disease; antimetabolites, alkylating agents, and antilymphocyte globulin have been tested. ${ }^{11-14}$ It seemed reasonable, therefore, to test an immunostimulant and the present trial has investigated the efficacy of levamisole used alone or in combination with sulphasalazine in patients with active ulcerative colitis. Treatment was continued for one year.

\section{Methods}

\section{PATIENTS}

Forty five patients in an acute attack of ulcerative colitis were entered into the trial. The purpose and

Address for correspondence: Dr Andrzej Hermanowicz. Gastroenterology Unit, Radcliffe Infirmary. Oxford OX2 6HE.

Received for publication 21 June 1983 the design of the trial was explained before obtaining the patient's consent. The details of the patients are shown in Table 1. The diagnosis of ulcerative colitis was made on commonly accepted criteria - that is, the present and past symptoms (bloody diarrhoea, fever, loss of weight, etc), sigmoidoscopic appearances, histological examination of a rectal biopsy specimen, and the appearance of a barium enema. All cases were referred to the International Programme for Inflammatory Bowel Disease organised by the Research Committee of OMGE and proved to meet $99.9 \%$ of their diagnostic criteria. The ulcerative colitis activity index (UCAI) was defined according to our modification of the Talstad and Gjone criteria ${ }^{15}$ (Table 2). Patients with a score of 6-15 were considered as having mild ulcerative colitis, a score of greater than 15 represented severe disease, while a score of 5 or less was regarded as remission. On entry into the trial, patients were randomly allocated to one of the three groups: (a) sulphasalazine, $6 \mathrm{~g}$ daily until remission occurred, followed by 3-4 g daily as maintenance therapy, (b) levamisole $150 \mathrm{mg}$ orally twice a week for the first two weeks and then once a week thereafter, (c) levamisole plus sulphasalazine in the doses used in groups (a) and (b). Allocation was performed using a table of random numbers. 
Table 1 Details of patients

\begin{tabular}{|c|c|c|c|}
\hline & Sulphasalazine & Levamisole & $\begin{array}{l}\text { Sulphasalazine } \\
\text { and levamisole }\end{array}$ \\
\hline Number & 15 & 15 & 15 \\
\hline Age in years & $36 \cdot 0 / 20-66 /$ & $40 \cdot 3 / 22-73 /$ & $43 \cdot 7 / 20-74 /$ \\
\hline Male/female & $9 / 6$ & $8 / 7$ & $7 / 8$ \\
\hline Duration of the disease in years & $5 \cdot 4 / 0 \cdot 4-13 \cdot 0 /$ & $5 \cdot 2 / 0 \cdot 2-18 \cdot 0 /$ & $6 \cdot 3 / 0-15 \cdot 0 /$ \\
\hline Number of previous attacks $1-2$ & 7 & 9 & 7 \\
\hline 3-9 & 6 & 4 & 7 \\
\hline 10 & 2 & 2 & 1 \\
\hline \multicolumn{4}{|l|}{ Mean symptom free period before } \\
\hline last attack in months & $5 \cdot 4 / 0-16 /$ & $9 \cdot 1 / 0-24 /$ & $8 \cdot 2 / 0-20 /$ \\
\hline Disease extent: rectal & 2 & 4 & 3 \\
\hline left side colon & 11 & 11 & 10 \\
\hline total colon & 2 & - & 2 \\
\hline \multicolumn{4}{|l|}{ Treatment in previous 6 months } \\
\hline sulphasalazine & 12 & 12 & 12 \\
\hline rectal steroids & - & - & 1 \\
\hline oral steroids & 1 & - & 1 \\
\hline
\end{tabular}

Each patient was given a diary card on which to record the daily number of stools, the presence or absence of blood, the degree of abdominal pain, temperature and body weight. The UCAI was measured on the first visit and every three months during the year of treatment. At each visit, sigmoid-

Table 2 Disease activity in ulcerative colitis. Modification of Talstad and Gjone classification ${ }^{15}$

\begin{tabular}{|c|c|c|c|}
\hline \multicolumn{3}{|c|}{ Disease activity parameters } & \multirow[t]{3}{*}{$\begin{array}{l}\text { Ulcerative colitis } \\
\text { maximum score }\end{array}$} \\
\hline Diarrhoea & $\begin{array}{l}3-5 \text { motions/day } \\
6-10 \text { motions/day }\end{array}$ & $\begin{array}{l}1 \\
2\end{array}$ & \\
\hline & $>10$ motions/day & 3 & \\
\hline \multirow[t]{2}{*}{ Fever } & $38-39^{\circ} \mathrm{C}$ & & \\
\hline & $>39^{\circ} \mathrm{C}$ & 2 & 2 \\
\hline Tachycardia & $>100 / \mathrm{min}$ & 2 & 2 \\
\hline Abdominal pain & & 1 & 1 \\
\hline \multirow[t]{2}{*}{ Weight loss } & $5-10 \mathrm{~kg}$ & 1 & \\
\hline & $>10 \mathrm{~kg}$ & 2 & 2 \\
\hline \multirow[t]{4}{*}{ Radiograph of colon } & slight & 1 & \\
\hline & moderate & 2 & \\
\hline & severe & 3 & \\
\hline & toxic & 4 & 4 \\
\hline \multirow[t]{2}{*}{ Proctoscopy } & slight & 1 & \\
\hline & severe & 2 & 2 \\
\hline \multirow[t]{2}{*}{ ESR } & $10-30 \mathrm{~mm} / \mathrm{h}$ & 1 & \\
\hline & $>30 \mathrm{~mm} / \mathrm{h}$ & 2 & 2 \\
\hline \multirow[t]{2}{*}{$\mathrm{Hb}$} & $10-11.8 \mathrm{~g} / 100 \mathrm{ml}$ & 1 & \\
\hline & $<10 \mathrm{~g} / 100 \mathrm{ml}$ & 2 & 2 \\
\hline Leucocytes & $>1 \times 10^{4} / \mathrm{ul}$ & 2 & 2 \\
\hline Thrombocytes & $>4 \times 10^{5} / \mathrm{ul}$ & 2 & 2 \\
\hline \multirow[t]{2}{*}{ Total protein } & $5 \cdot 6-6 \cdot 5 \mathrm{~g} / 100 \mathrm{ml}$ & 1 & \\
\hline & $<5.5 \mathrm{~g} / 100 \mathrm{ml}$ & 2 & 2 \\
\hline \multirow[t]{2}{*}{ Albumin } & $2 \cdot 6-3 \cdot 3 \mathrm{~g} / 100 \mathrm{ml}$ & 1 & \\
\hline & $<2.5 \mathrm{~g} / 100 \mathrm{ml}$ & 2 & 2 \\
\hline \multirow[t]{2}{*}{ Serum iron } & $51-70 \mathrm{ug} / 100 \mathrm{ml}$ & 1 & \\
\hline & $<50 \mathrm{ug} / 100 \mathrm{ml}$ & 2 & 2 \\
\hline Sum maximum score & & & 30 \\
\hline
\end{tabular}

oscopy was performed with biopsy and blood samples were obtained for a full blood count and ESR, serum iron, total protein, and albumin concentration. A barium enema was performed before entry into the trial and at the end of the one year treatment period. Supportive therapy in the form of vitamins and iron was prescribed as required.

\section{STATISTICS}

Results were analysed using the $\chi^{2}$ test and Student's $t$ test for paired and unpaired data. Significance was taken as $\mathrm{p}<0.05$.

Results

COMPARABILITY OF GROUPS

Patients in each group were comparable in age and sex distribution, duration of the disease, number of previous attacks, extent of disease and treatment during the six months before entering the trial.

\section{ULCERATIVE COLITIS ACTIVITY INDEX (UCAI)}

Figure 1 shows the UCAI for each group on entry into the trial and at each three month period during the subsequent year. At each time interval there were no significant differences between the groups. For all patients there was a fall in the UCAI during treatment between the groups. For all patients there was a fall in the UCAI during treatment regardless of which therapeutic regimen they were receiving.

Figure 2a shows that the daily number of stools each patient passed progressively diminished during treatment and there was a small rise in body weight during the trial period. No differences were seen between groups. Figure $2 \mathrm{~b}$ shows the laboratory 
Fig. I Effect of sulphasalazine. lev'amisole and sulphasalazine plus levamisole on ulcerative colitis activity. index (UCAI) score. Meain results and $S D$ are indicated.

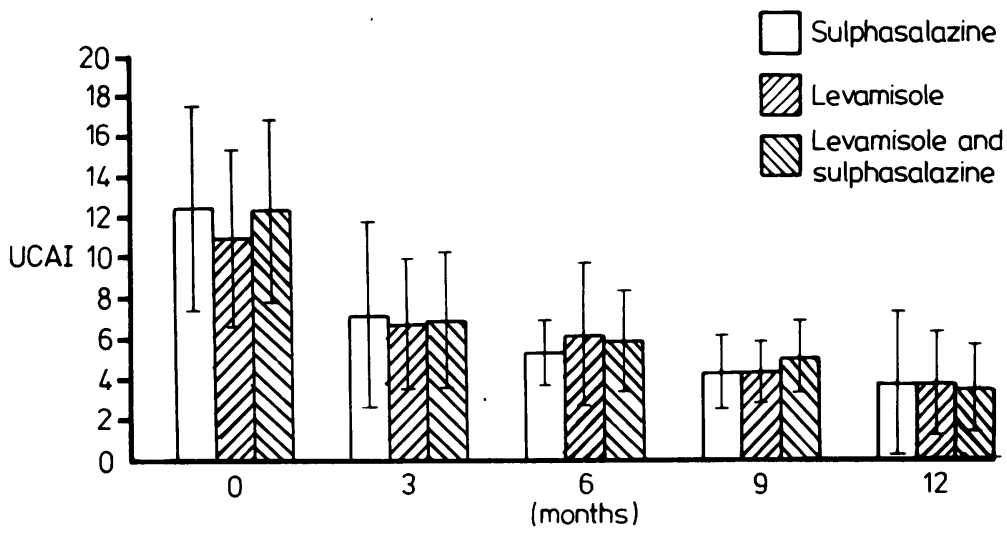

data. After six and 12 months of therapy, the ESR and platelet count was significantly higher in group (c) compared with group (a). All other clinical and biochemical parameters did not differ among the groups.

The sigmoidoscopic appearances are shown in Table 3.

\section{REMISSION AND RELAPSE RATES}

For groups (a) and (c), 10 patients $(66.6 \%)$ in each group went into remission on treatment compared with seven patients $(46.6 \%)$ in the levamisole treated group (group b). This difference was not significant. In group (b), three patients $(20 \%)$ relapsed compared with only one patient $(6.6 \%)$ in each other group. This difference was not significant.

\section{SIDE EFFECTS}

Side effects were observed in six patients from group (c) (Table 4). In groups (a) and (b), side-effects were observed in three and four patients respectively. Two patients in group (b) and two in

Table 3 Proctoscopic findings during ulcerative colitis therapy

\begin{tabular}{|c|c|c|c|c|c|c|c|c|c|}
\hline \multirow[b]{2}{*}{$\begin{array}{l}\text { Duration of treatment } \\
\text { (months) }\end{array}$} & \multicolumn{3}{|c|}{ Sulphasalazine } & \multicolumn{3}{|c|}{$\begin{array}{l}\text { Sulphasalazine } \\
\text { and levamisole }\end{array}$} & \multicolumn{3}{|c|}{ Levamisole } \\
\hline & 0 & 6 & 12 & 0 & 6 & 12 & 0 & 6 & 12 \\
\hline Patients (no.) & 15 & 14 & 14 & 15 & 15 & 12 & 15 & 14 & 10 \\
\hline Ulcers & 15 & 8 & 1 & 15 & 4 & 3 & 15 & 6 & 2 \\
\hline Friability (bleeding & & & & & & & & & \\
\hline to touch only) & 15 & 11 & 8 & 15 & 7 & 3 & 15 & 11 & 3 \\
\hline Spontaneous bleeding & 15 & 10 & 7 & 15 & 8 & 2 & 15 & 10 & 2 \\
\hline
\end{tabular}

group (c) had such severe side effects (headache, leucopenia, skin rash) that treatment had to be stopped.

\section{Discussion}

The efficacy of levamisole in a variety of inflammatory disorders is well documented. ${ }^{16-20}$ The drug may also be useful in the management of Crohn's disease. ${ }^{21-23}$ In ulcerative colitis, levamisole was not effective in a group of seven patients but clinical details of these patients was poorly documented. ${ }^{21}$

The present study has compared levamisole with sulphasalzine in patients with active ulcerative colitis. Although the UCAI was reduced in all three treatment groups, fewer patients went into remission - that is, UCAI 5 - on levamisole compared with those receiving sulphasalazine. The subsequent relapse rate was higher in the levamisole treated group than in those receiving sulphasalazine. Those differences, however, were not significant. The combination of sulphasalazine and levamisole had no benefit over sulphasalazine alone.

Table 4 Number of side effects. 1-during 0-6 months, 2-6-12 months, 3-withdraw'al of the drugs caused by the side effects

\begin{tabular}{|c|c|c|c|c|c|c|c|c|c|}
\hline & \multicolumn{3}{|c|}{ Sulphasalazine } & \multicolumn{3}{|c|}{$\begin{array}{l}\text { Sulphasalazine } \\
\text { and lev'amisole }\end{array}$} & \multicolumn{3}{|c|}{ Levamisole } \\
\hline & 1 & 2 & 3 & 1 & 2 & 3 & $l$ & 2 & 3 \\
\hline Indigestion & 1 & 1 & - & - & - & - & 1 & - & - \\
\hline Headache & - & - & - & - & 1 & 1 & 1 & 1 & 1 \\
\hline Leukopenia & - & - & - & - & 1 & 1 & - & - & - \\
\hline Skin rash & 1 & - & - & 1 & 1 & - & - & 1 & 1 \\
\hline Mouth ulcers & - & - & - & - & 1 & - & - & - & - \\
\hline Oedema cruris & - & - & - & - & 1 & - & - & - & - \\
\hline Total & 2 & 1 & - & 1 & 5 & 2 & 2 & 2 & 2 \\
\hline
\end{tabular}



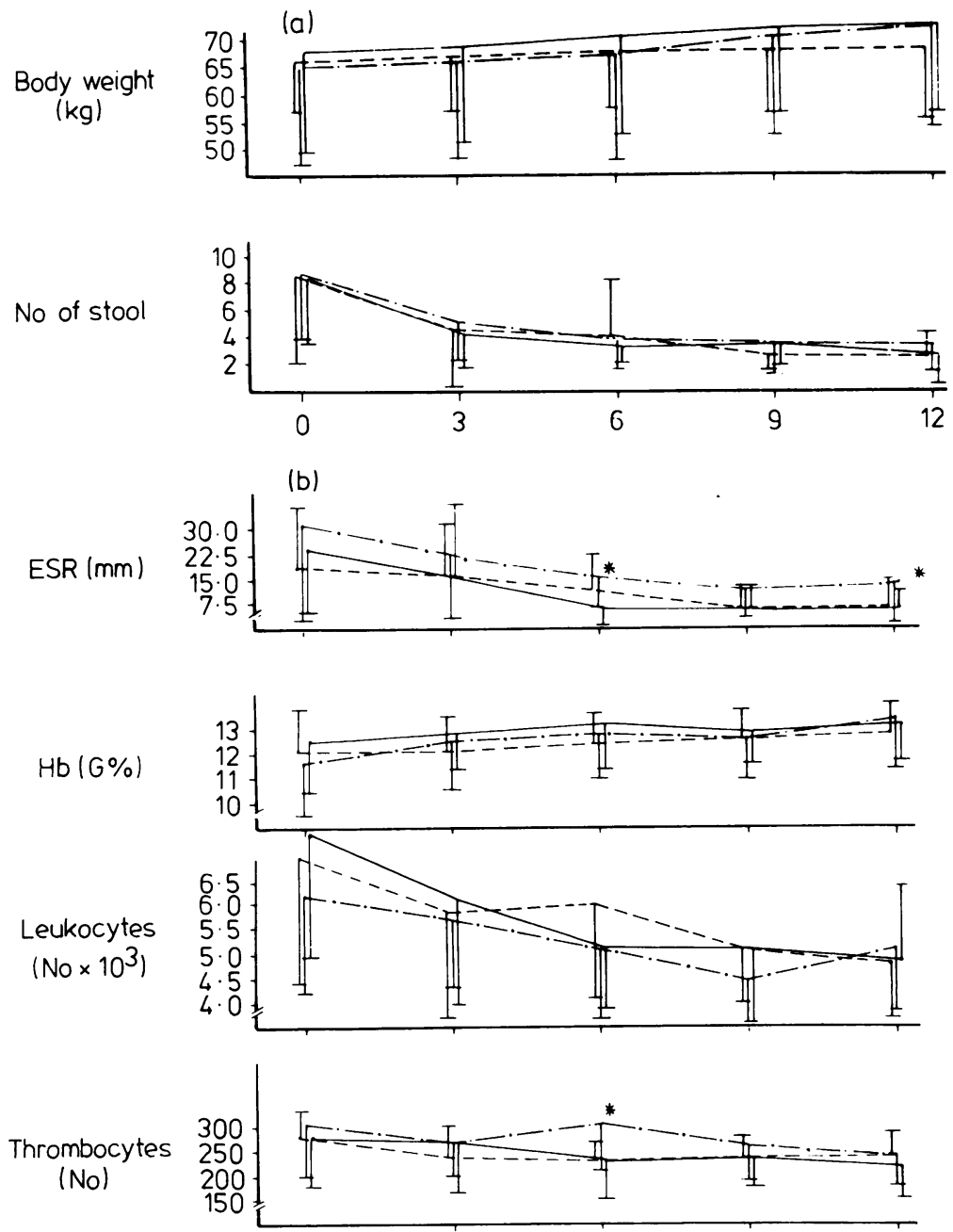

Fig. 2 Effect of sulphasalazine (-), levamisole (-- ) and sulphasalazine used together with levamisole (-.-.-) on clinical (a) and on biochemical (b) indices of disease activity. ${ }^{*} p<0.05$

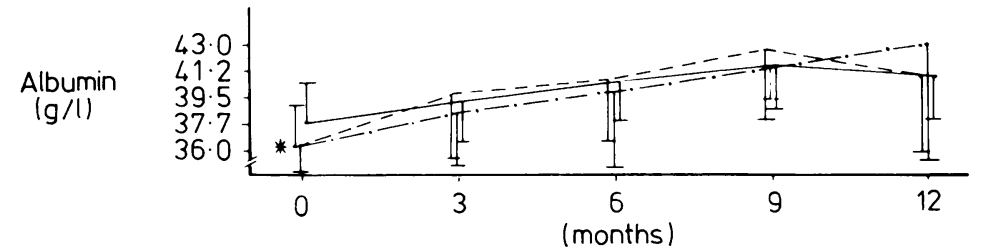

The comparatively low dose of levamisole used in this trial has been shown to be associated with few side effects although its immunostimulatory properties are maintained. ${ }^{24}$ Twenty six per cent of patients receiving levamisole, however, developed side effects which is similar to that reported in other series using a higher dosage. ${ }^{8}$ Thus no reduction of side effects was seen using the lower dose. In

conclusion, the results of this trial suggest that levamisole is of little benefit in the management of ulcerative colitis. They may also suggest that the pathogenesis of the disease is not a result of an impaired immune response.

Levamisole tablets were kindly supplied by $\operatorname{Dr} J$ Symoens from Janssen Pharmaceutica, Beerse, 
Belgium. We would like to thank Dr D P Jewell of the Gastroenterology Unit, The Radcliffe Infirmary, Oxford, for his helpful criticism and advice.

\section{References}

1 Perlmann PS, Hammarstron R, Lagercrantz R, Gustaffson BE. Antigen from colon from germ free rats and antibodies in human ulcerative colitis. Ann NY Acad Sci 1965; 124: 377-94.

2 Jewell DP, Mac Lennan IC. Circulating immune complexes in inflammatory bowel disease. Clin Exp Immunol 1973; 14: 219-26.

3 Hermanowicz A, Nawarska Z. Chemotaxis and random migration of polymorphonuclears leukocytes in ulcerative colitis examined by the agarose method. Scand J Gastroenterol 1981; 16: 961-6.

4 Hermanowicz A, Borys D, Nawarska Z, Stadnicki A: Polymorphonuclear leukocyte function in ulcerative colitis. Gastroenterol Clin Biol 1982; 6: 863-8.

5 Victorino MM, Hodgson HJF. Alteration in $\mathrm{T}$ lymphocyte subpopulations in inflammatory bowel disease. Clin Exp Immunol 1980; 41: 156-65.

6 Hodgson HJF, Wands JR, Isselbacher KJ. Decreased suppressor cell activity in inflammatory bowel disease. Clin Exp Immunol 1978; 32: 451-8.

7 Shorter RG, Huizenga KA, Remine SG, Spencer RJ. Effect of preliminary incubation of lymphocytes with serum on their cytotoxicity for colonic epithelial cells. Gastroenterology 1970; 58: 843-50.

8 Symoens J, Rosenthal M. Levamisole in the modulation of the immune response: the current experimental and clinical state. J Reticuloendothel Soc 1977; 21: 175-221.

9 Renoux G. The general immunopharmacology of levamisole. Drugs 1980; 19: 89-99.

$10 \mathrm{Yu}$ DTW, Clements PJ, Paulus HE et al. Human lymphocyte subpopulations: effect of corticosteroids. $J$ Clin Invest 1974; 53: 565-71.
11 Sachar DB, Present $\mathrm{DH}$. Immunotherapy in inflammatory bowel disease. Med Clin N Am 1980; 62: 173-83.

12 Jewell DP, Truelove SC. Azathioprine in ulcerative colitis: final report on controlled therapeutic trial. $\mathrm{Br}$ Med J 1974; 4: 627-30.

13 Eisenbeth R, Oberling F. Le traitement par les immunosuppresseurs de certaines rectocolites hemorrhagiques et purulentes: le role eventuel des lymphocytes. Presse Méd 1969; 77: 2141-2.

14 Heyworth MH, Truelove SC. A therapeutic trial of anti-lymphocytic globulin in acute ulcerative colitis. Digestion 1980; 20: 221-4.

15 Talstad I, Gjone E. The disease activity of ulcerative colitis and Crohn's disease. Scand J Gastroenterol 1976; 2: 403-8.

16 Wilton JMA. Levamisole in chronic inflammatory states. J Rheumatol 1978; 5: suppl 4, 101-13.

17 Lehner T, Wilton JMA, Ivanyi L. Double blind crossover trial of levamisole in recurrent aphtous ulceration. Lancet 1976; 2: 926-9.

18 Multicentre Study Group. Levamisole in rheumatoid arthritis. A randomised double-blind study comparing two dosage regimens of levamisole with placebo. Lancet 1978; 2: 1007-12.

19 Symoens J, Brugmans J. Treatment of recurrent aphtous stomatitis and herpes infections with levamisole. Br Med J 1974; 4: 592.

20 Allen DE, Kaplan B, Pinnel SR. Levamisole and skin disease. Int J Dermatol 1978; 17: 287-91.

21 Bertrand J, Renoux G, Renoux M, Palat A. Maladie de Crohn et levamisole. Nouv Presse Méd 1974; 3: 2265.

22 Segal AW, Levi AJ, Loewi G. Levamisole in the treatment of Crohn's disease. Lancet 1977; 2: 382-4.

23 Bertrand J, Renoux G, Vandooren M. Le traitment de la maladie de Crohn par le levamisole. Ann Gastroenterol Hepatol 1977; 13: 361-6.

24 Di Perri T, Auteri A, Pasini FL, Mattioli F. A weekly oral dose of levamisole in the treatment of rheumatoid arthritis associated with E-rosette lymphocytes reduction. Eur J Rheumatol Inflamm 1978; 1: 155-64. 